\title{
Commentary
}

\section{Media blind spot over West Papua}

MAIRE LEADBEATER

Indonesia Human Rights Committee

TNDONESIA is trying to build an international reputation as a nascent democracy and is proud of having been re-elected in 2007 to the United Nations Human Rights Council for a three-year term. But the problems in West Papua ${ }^{1}$ makethisdemocratic reformstoryquestionable. While Indonesia keeps this troubled province off limits to foreign journalists and human rights investigators, Indonesia's human rights credibility should be critically examined.

Indonesia's incorporation of West Papua has been contested ever since it took control in 1963. West Papua's fate was sealed by a 1969 'Act of Free Choice' which is known as the 'Act of No Choice' by the Papuans, since it was carried out under extreme duress and only 1022 men were allowed to vote (Saltford, 2003). The province remains heavily militarised and opposition to Indonesia's rule persists. Grave human rights abuses have been exposed, especially in the post-Suharto years when Papuan nationalists have begun to work with an international solidarity movement to publicise their problems. Some academics consider the survival of the West Papuan people is under threat because of cumulative impacts including poverty, HIV/AIDs, loss of life-sustaining forests, and uncontrolled migration (Wing \& King, 2005).

Rarely do international journalists get official approval to visit West Papua. While the West Papua story stays out of international headlines, public realisation and concern remains low. There is little awareness that this Melanesian territory shares the island of New Guinea with its Pacific neighbour Papua New Guinea.

Solidarity activists have a struggle to make the issue better known outside the human rights community. As a New Zealand activist, I have found that when we host a West Papuan human rights leader, it is hard to 
persuade local journalists (or perhaps their editors) that they should make time to interview our guest. For example, when Reverend Socrates Sofyan Yoman, head of the Papuan Baptist Churches, toured New Zealand in 2006 no metropolitan daily published an interview or quoted his views. Radio New Zealand international is an exception to this pattern. It frequently interviews West Papuan representatives with varying political views both those who are on the ground as well as those on exile.

In a departure from previous practice, Indonesia allowed two United Nations rapporteurs to visit West Papua in 2007. Hina Jilani, the UN Special Representative to the Secretary-General on Human Rights Defenders, and Manfred Nowak, UN Special Rapporteur on Torture. A third rapporteur, Philip Alston, whose brief is extrajudicial killings, was not permitted to visit. Hina Jilani (United Nations, 2007) highlighted her concerns about the military and police harassment and intimidation of human rights activists. She referred to 'credible reports' of arbitrary detention, torture, and harassment of those who sought to investigate human rights violations. Some of the people she met with reported being targeted with death threats and intimidation after her departure. These reports were not covered by mainstream media in New Zealand.

In September 2007, Lucy Williamson, a BBC Jakarta correspondent, gained a rare permit to visit the Central Highlands to report on the opening of an independent radio network, Newsroom $68 \mathrm{H}$, and an associated hydro-electric dam. She also gave a graphic account of underdevelopment and extreme poverty in the area and reported on allegations of human rights abuses.

Some West Papuans believe that access may have tightened up again since the BBC visit. Access did not seem to be a problem for one journalist, Trish Sentori, who writes for the English language Jakarta Post. She was hosted by the giant gold and copper mine Freeport McMoran and her articles were human interest - small Papuan woman drives an enormous earth moving truck - rather than dealing with political or environmental issues (The Jakarta Post, 25 November 2007).

However, when West Papuan academic Father Neles Tebay wrote an opinion article entitled 'Papuan peace lovers want troops to leave' and calling for greater respect for Papuan rights and demilitarisation (The Jakarta Post, 6 November, 2007), there was a strong rejoinder. The Indonesian military (known by its acronym TNI) wrote that Tebay's op-ed 'harmed the institution of the TNI and negated Indonesian integrity'. The TNI spokesperson, Vice Marshall Sagom Tamboen, sounded an intimidating note when he 
accused Tebay of supporting 'those wishing to see Indonesia's disintegration' (The Jakarta Post, 1 December, 2007).

One of the strongest international advocates for West Papuan selfdetermination in recent years has been United States Congressman Eni Faleomavaega, a Samoan. He has successfully rallied support from Congressional colleagues, particularly those in the Black Caucus and he has promoted the international campaign for the UN to review its role in the 'Act of Free Choice'. He currently holds the post of Chairman of the Foreign Affairs' Subcommittee on Asia, the Pacific, and the Global Environment, so when he was refused permission to visit West Papua in July, the snub was highly publicised. But Congressman Faleomavaega himself adopted a conciliatory approach and in November the Indonesian authorities facilitated a brief tour for him and the US Ambassador.

Brief is the operative word. In the course of two days the US guests were rushed in and out of Timika-where Freeport McMoran mine is located-Biak and Manokwari. The itinerary did not include the capital, Jayapura, and it certainly did not include any interviews with journalists. Thousands of Papuans wanted to greet the congressman and were waiting at the places they believed he would visit. However, they were outmaneuvered by police who managed to ensure the US guests had time only for formal meetings with the governor and a handful of other political leaders. In Manokwari the authorities were so concerned to 'protect' their guests that they transported the US pair along a badly potholed back road from the airport into town. According to an emailed report from West Papua, a few determined Papuans managed to garland him as he was ushered through the airport on his way to Biak and others defied the authorities to rush on to the airport tarmac with banners as the plane was taking off (Warinussy, 2007). To my knowledge, no New Zealand journalist has attempted recently to break through the cordon to get first hand experience in West Papua. An important story remains untold.

\section{New Zealand foreign policy and West Papua}

There is another interlinked story which is also not being told-about New Zealand's role in West Papua and New Zealand's ongoing support for Indonesia. It is interesting to note that New Zealand diplomats do not get the run around when they request permission to visit West Papua. New Zealand puts high value on its good bilateral relationship with 
Indonesia and has worked to put the relationship on a good footing again after a period of instability following East Timor's liberation and the horrendous Indonesian military and militia violence which preceded it. New Zealand Embassy staff make regular visits to West Papua to oversee aid projects, including a special training programme in conflict resolution and community policing for the West Papuan police (Peters, 2007).

The New Zealand government has chosen a strategy of 'engagement' focused on funding aid projects that are acceptable to Indonesia. The government is careful to signal its continuing support for Indonesia's 'territorial integrity'. The military ties which were suspended in 1999 in response to the cataclysmic violence in East Timor were quietly resumed in 2006 (Peters, 2006), and the government has said little on the issue of impunity despite the fact that many of those responsible for crimes against humanity in East Timor have been promoted to new posts in West Papua and other conflict areas.

Australian academic and writer on West Papua, Dr Peter King (2006), describes both the Indonesian military and police as 'quasi states' to illustrate their deep involvement in corruption and lack of accountability to the civilian government. In West Papua he notes that of the 137 cases brought by the police in a logging scandal in 2005, not one has resulted in conviction.

In 2000 there was a tantalising window on New Zealand's West Papua diplomacy when the government seemed prepared to risk the possibility of Indonesian disapproval. In October that year, the Indonesia Human Rights Committee hosted the international representative of the Free West Papua Movement (OPM), John Ondawame. NZ Foreign Minister Phil Goff agreed to meet him against his officials' advice (MFAT, 2000a). As Ondawame arrived at Parliament on October 18, Green Party Foreign Affairs spokesperson Keith Locke staged a colourful welcome as he and several MPs-including Labour colleagues - held aloft several nationalist Morning Star flags. Later, Goff said he was also willing to meet privately with the Papua Presidium's charismatic leader Chief Theys Eluay (MFAT, 2000b), although this visit never eventuated before Theys Eluay's death at the hands of the Indonesia military in November 2001.

At the UN Millennium Summit in New York the leaders of Nauru and Vanuatu had both spoken in support of self-determination for their fellow Melanesians in West Papua. (Sope, 2000; and Dowiyogo, 2000) and were proposing to raise the issue at the Pacific Islands Forum, in Kiribati, greatly to the concern of Indonesia. 
For a few months New Zealand was the focus of a diplomatic offensive from both Indonesia and West Papuan representatives. Indonesia sent a delegation of pro-Indonesian Papuan MPs and officials to coincide with John Ondawame's visit. The official's report written to summarise both these visits suggests that New Zealand was contemplating taking a more robust stand. In his discussions with the Indonesian delegation, the then Minister referred to recent violence in Papua and stressed that while New Zealand wished to see a 'stable, democratic, prosperous and united Indonesia. Indonesia's unity was dependent on how Jakarta sought to resolve separatist tensions, rather than external statements about Indonesia's territorial integrity' (MFAT, 2000c).

After the Pacific Islands Forum, leaders of the pro-independence Papua Presidium called on Foreign Minister Goff to ask New Zealand to play a mediation role as a 'neutral third party'. While the delegation was told this was unlikely to happen 'given Indonesia's views on outside involvement in matters of territorial integrity' (MFAT, 2000d), New Zealand's 'offer' to help with dialogue was discussed in newspaper articles in Australia and New Zealand (West Papua requires cautious approach, 2000; Indonesia plans regional summit, 2000).

By the end of 2000. the Papuan 'spring' was over-key independence leaders, including Theys Eluay, had been detained - and Brimob police had just perpetrated a grave crime against defenceless students-killing three and beating and torturing and jailing more than 100 others. (King, 2004, p.33)

But the 'spring' in New Zealand-West Papua diplomacy was also coming to an end (New Zealand Herald, 8 October 2002). New Zealand warmly welcomed the 2001 Special Autonomy legislation for Papua, and ever since official statements express the view that the' best route to a peaceful solution in Papua' is the full implementation of the special autonomy package (Goff, 2003). Not only has New Zealand chosen to work with the wrong people, there seems to be a new determination on the part of officials to distance themselves from any group or person connected to the self-determination cause.

A heavily censored copy of the December 2006 report by the Second Secretary of the New Zealand Embassy has been released to IHRC under the Official Information Act.

The report stresses that 'New Zealand's objectives in Papua are to support the full implementation of the Special Autonomy Law on Papua (OTSUS) in the context of our commitment to the territorial integrity of the Republic of 
Indonesia (NKRI) and to do what we can to encourage stronger adherence to basic human rights standards in the province'.

The Embassy official was anxious to make it clear that the government distanced itself from 'some' NGOs. 'We fully appreciate that in a free society New Zealand NGOs have every right to make their views known and that some will continue to support the Papuan separatist cause and inevitably irritate the Indonesian authorities. At the same time, care is needed to ensure that there is no justification for accusations that NZAID funding is being channeled to NGO activities that support Papuan separatism and thus undermine New Zealand government policy' (NZ Embassy, 2007).

New Zealand now has privileged and rare access to West Papua. This includes access to 'sensitive' sites such as the Central Highlands where conflict with the military has been at its most intense. Officials are also able to visit the controversial Freeport McMoran Mine (NZ Embassy, 2006) and have witnessed illegal logging inside Wasur National Park' (Van der Vloodt, 2007).

In recent years, the West Papuan movement has united around the call for peaceful dialogue with Indonesia, and a recent leaders' summit formed a new alliance, the West Papua Coalition for National Liberation (WPCNL) (Makabory, 2007). The new umbrella organisation includes the Free Papua Movement (OPM) and is calling for the involvement of an internationally recognised mediator. Vanuatu is proposing to call on the United Nations Decolonisation Committee to re-inscribe West Papua on its list of nonself-governing territories. New Zealand is not supporting these initiatives, and the Green Party is the only Parliamentary voice which consistently takes a stand for West Papua's right to self-determination and in support of Melanesian initiatives. ${ }^{2}$

During the Indonesian occupation of East Timor, New Zealand played a key role in the United Nations supporting the Indonesian position, and now the same scenario is playing out over West Papua. There are exceptions, including the work of Scoop writer Joseph Barratt (2007), but the New Zealand media is essentially ignoring this important story.

\section{Notes}

1. In 2001, Indonesian President Abdurrahman Wahid conferred the name 'Papua' on the province which had previously been known as Irian Jaya. However, Papuan nationalists and their supporters use 'West Papua', the name chosen in 1961 by the 
New Guinea Council when the Dutch were beginning to prepare the territory for independence.

2. The Green Parliamentarians have flown the Papuan Morning Star flag on the steps of Parliament many times, most controversially during the first visit of Indonesian President Susilo Bambang Yudhoyono to New Zealand on 6 April 2005.

\section{References}

Dowigo, B. (2000). President of Nauru. Statement at United Nations Millenium Summit, New York. September 7.

West Papua requires cautious approach. (2000, December 22). Editorial. The Evening Post.

Goff, P. Minister of Foreign Affairs, (2003). Minister of Foreign Affairs: Letter to Indonesia Human Rights Committee, December 10.

King, P. (2004). West Papua and Indonesia since Suharto. NSW: University of New South Wales Press.

King, P. (2006). Korupsi dan Disintegrasi in Indonesia since Suharto. Policy and Society (Special Issue: Asia Early this Century: Contested Polities and Mentalities), 25(4), 3-22.

Makabory, P. (2007, October 2). Media Release.West Papua Coalition for National Liberation.

Ministry of Foreign Affairs and Trade (2000a). Memorandum to the Minister. October 6.

Ministry of Foreign Affairs and Trade (2000b). Indonesia: Papua. Cable to New Zealand Embassy, Jakarta, August 22.

Ministry of Foreign Affairs and Trade (2000c). Indonesia: West Papua. Cable to New Zealand Embassy, Jakarta. October 31.

Ministry of Foreign Affairs and Trade (2000d). Indonesia: West Papua: Visit to New Zealand by Papuan Council Representatives. Memo to New Zealand Embassy Jakarta. November 30.

New Zealand Embassy Jakarta (2007). Indonesia, Papua and Perceptions of New Zealand. Cable to Ministry of Foreign Affairs, Wellington, January 30.

New Zealand Embassy, Jakarta, (2006). Report of the DAS [Defence Attaches] Visit to West Papua 17-21 January 2006.

Parkinson, T. (2000, December 9). Indonesia plans regional summit, The Age.

Peters, W. (2007, October 3). Minister of Foreign affairs letter to Indonesia Human Rights Committee.

Peters, W. (2006, December 13). Minister of Foreign Affairs-Security policy responses to a challenging world. Address to the Centre for Strategic Studies conference The Asia Pacific: Future strategic perspectives,. Wellington: Victoria University.

Saltford, J. (2003). The United Nations and the Indonesian takeover of West Papua, 1962-1969. London: Routledge Curzon. 
Wing, J and King, P. (2005).Genocide in West Papua? A Report for the Centre for Peace and Conflict Studies, University of Sydney and ELSHAM, Jayapura, Papua, August.

Sope, B. (2000). Prime Minister of Vanuatu. Statement at United Nations Millenium Summit, New York, September 7.

Van der Vloodt, F. (2007). NZAID Manager, New Zealand Embassy, Jakarta. Note for File: Papua: Development Issues, February 12.

United Nations, (2007, June 12). Media Release: Special Representative of SecretaryGeneral on Situation of Human Rights Defenders concludes visit to Indonesia.

Warinussy, Y. C. (2007, November 27). West Papua report. Published by TAPOL, the UK-based Indonesia Human Rights Campaign.

Williamson, L. (2007). In Pictures: Papua gets connected. news.bbc.co.uk/2/shared/ spl/hi/picture_gallery/07/asia_pac_papua_gets_connected/html/1.stm

Maire Leadbeater is spokesperson for the Auckland-based Indonesia Human Rights Committee and author of Negligent Neighbour: New Zealand's Complicity in the Invasion and Occupation of Timor-Leste (Craig Potton, 2006).

maire@clear.net.nz

\section{PACIFIC MEDIA CENTRE}

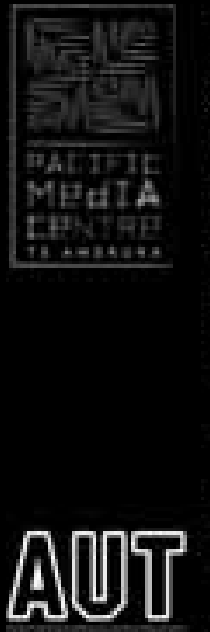

The Pacific Media Centre (Te Amokura) is the only media research and cammunity resource centre of its kind in Aotearoa/New Zealand and has a strategic focus on Măori, Pasifika and diversity media and community development: it was established by AUT University's Faculty of Design and Creative rechnologies in e.07? having evolved from a cluster of researchiand community collaborations within the School of Comminitation Strfle?

PMC activities include.

- International book and research putlicatices

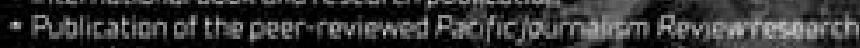
journal

- Publication of Pacific Media Centre Online as a media rescurce andis posteraduate outlet

- Publicatian of Pacfic Media Watch a reg/thal media monitoring Secylze

- joirnalism and media research opportunities

- Asia-Pacfic internships for postgraduatestudents.

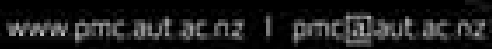

